\title{
Seasonal changes of fouling-forming microalgae on lithium manganese oxide disks in seawater, East Sea, Republic of Korea
}

\author{
Joo-Ae Kim ${ }^{1,3}$, Seulki Jeong', Kang-Sup Chung ${ }^{2}$, Hye-On Yoon ${ }^{1+}$ \\ ${ }^{1}$ Korea Basic Science Institute, Seoul center, 6-7, Inchon-ro 22-gil, Seongbuk-gu, Seoul, Republic of Korea, 02855 \\ ${ }^{2}$ Korea Institute of Geoscience and Mineral Resources, Gajeong-dong, Yuseong-gu, Daejeon Republic of Korea, 34132 \\ ${ }^{3}$ Korea University, Department of Earth and Environmental Science, 145 Anam-ro, Seongbuk-gu, Republic of Korea, 02841
}

\begin{abstract}
For investigation of biofouling characteristics of marine microalgae on lithium manganese oxide disk (LD), which is manufactured for recovery of mineral resources from seawater, we carried out an exposing test for LD at Okgye, East Sea, Korea. The amount and species composition of the attached microalgae on the LD surfaces were determined based on the exposing period and season. The immersion test was conducted for $7 \mathrm{~d}, 14 \mathrm{~d}$ and $21 \mathrm{~d}$ for each of the three different seasons of May, August and October. The number of microalgae attached to the LD is dependent in season and exposing duration. In May and October, the microalgae adhered approximately $4,000 \mathrm{cells} / \mathrm{cm}^{2}$ after $7 \mathrm{~d}$ and after $14 \mathrm{~d}$, more than 2-fold were attached that exceeding 10,000 cells $/ \mathrm{cm}^{2}$. In spring and summer, centric diatom, Guinardia sp. and Cyclotella sp. were dominated in seawater, and they predominantly adherent in short exposure periods of within $7 \mathrm{~d}$. However, dominant adherent species were succeeded to Cylindrotheca sp., pennate diatom, as longer exposure times. The microalgae morphology, which favored attachment was also a major cause of prolonged fouling upon exposure of LD surface.
\end{abstract}

Keywords: Biofouling, Cylindrotheca Closterium, Diatom, Guinarida sp., lithium manganese oxide, Navicular sp.

\section{Introduction}

Marine biofouling is a serious concern to offshore installations, which are constructed for various purposes such as marine vessels, the leisure industry, antifouling development, and resource recovery [1-3]. Biofouling increases water flow resistance and corrosion of artificial surfaces [4,5] and results in serious economic losses [6-8]. The biofouling proceeds through several stages: formation of an organic film that biochemically conditions the surface, bacteria adherence and primary colonization, secondary colonization by unicellular eukaryotes, and tertiary colonization, which defines the macro-fouling stage [2]. In the early fouling process, the microorganisms rapidly form a biofilm on the submerged surface; the biofilm is a major factor affecting the attachment and growth of diatoms.

Diatom species have been reported to be the major constituents of biofilms in marine environment and due to the EPS (extracellular polymeric substances) secreted from the raphes or cell walls of diatom, it becomes easy to adhere to sediment particles or artificial surfaces. Therefore, diatom which have high adhesion capacity, have a significant effect on the function of submerged surfaces in marine environments. Studies regarding diatom species in biofouling investigation are exceptionally important because diatom plays a significant role in the settlement of macro organisms such as barnacles [9-11]. Numerous studies have been conducted regarding initial biofouling by microorganisms such as bacteria and algae, which have defined cell morphology, adhesion mechanisms, physical and chemical properties of the adhesive itself, as well as interactions with various artificial surfaces. Shim et al. [12] evaluated the species of diatoms attached to several types of artificial substrates exposed at Incheon Port such as glass, acrylic, titanium, copper, and anti-fouling (AF) coated slide glass. Patil and Anil [13] assessed biofouling by diatoms exposing the soil-simulated fiber and coupon-shaped glass at Dona Paula Bay, India, and Yang et al. [10] studied the characteristics of seasonal fouling on the glass panels. In the case of Munda [14], the concrete plate was exposed to predict the attachment of diatom species in the rock environment and Mitbbavkar and Anil [5] evaluated seasonal changes of diatoms
This is an Open Access article distributed under the terms of the Creative Commons Attribution Non-Commercial License (http://creativecommons.org/licenses/by-nc/3.0/) which permits unrestricted non-commercial use, distribution, and reproduction in any medium, provided the original work is properly cited.

Copyright (C) 2021 Korean Society of Environmental Engineers
Received January 28, 2020 Accepted May 17, 2020

${ }^{\dagger}$ Corresponding author

Email: dunee@kbsi.re.kr

Tel: +82-6943-4192

ORCID: 0000-0001-9212-3208 
species on stainless steel and polystyrene surfaces. Hunsucker et al. [15] studied the fouling characteristics according to the position (head and side) of an in-service ship and anti-fouling types of paints. Based on these studies, it can be observed that specific diatoms differ in terms of season, exposure location, duration, and materials of the artificial substrates. Therefore, to control biofouling of various types of exposed materials in seawater, area-material-specific fouling species studies should be conducted.

The $\mathrm{LD}$ (disk type of lithium adsorbents) used in the experiment is a lithium manganese oxide (LMO) material developed by the Korea Institute of Geoscience and Mineral Resources for lithium recovery from seawater. The Korea Institute of Geoscience and Mineral Resources has developed and evaluated various types of adsorption materials for the recovery of dissolved resources in seawater during a long period of time. In particular, a lithium adsorption material based on LMO was developed and patented by the U.S. Patent $[16,17]$ and published several papers related to the developed material properties [18-21]. For lithium recovery in seawater, a pilot study was produced and in parallel, a biofouling evaluation study was conducted. As first, started with a study of fouling by bacteria, an early stage of biological fouling. Powder type adsorbents were exposed in Sacheon, East Sea for $30 \mathrm{~d}$ to evaluate the control of fouling species by zinc oxide antifouling agents [3]. A surface observation method was applied [22] to find out the actual fouling shape on the surface of the adsorbent material, and a study was conducted to evaluate the adhesion to the shape and surface area, such as circular, powder, and rod shapes [23]. The study of contamination by plankton, which could lead to the next major contamination from bacteria, was started [24]. The adsorption material used in this study is made by molding lithium manganese oxide particles into a disk shape.

We evaluated the biofouling characteristics of microalgae communities due to seasonal changes and exposure duration on the surface of lithium manganese oxide disk (LD) exposed in the Okgye Sea in Korea. To investigate the seasonal and temporal distributions of the fouling microalgae, the $\mathrm{LD}$ were exposed to dynamic seawater for a certain period and collected after $7 \mathrm{~d}, 14 \mathrm{~d}$, and $21 \mathrm{~d}$ in May, August, and November 2013, respectively, in the Okgye Sea in Korea. Cell counting and identification of $\mathrm{LD}$ surfaces were conducted using an optical microscope and a scanning electron microscope (SEM).

\section{Experiments}

\subsection{Study Area}

The investigations were conducted near the Okgye Sea $\left(37.37^{\circ}\right.$ $\mathrm{N}, 129.04^{\circ} \mathrm{E}$ ), Gangneung, in the mid-latitude of the east coast of Korea. This installation is located at a $1 \mathrm{~km}$ distance from the Seawater Lithium Research Center and $750 \mathrm{~m}$ from the coast. Seawater depth was observed between 12 and $15 \mathrm{~m}$. During the experimental periods, the average values of surface temperature was $13.4 \pm 0.7^{\circ} \mathrm{C}, 26.4 \pm 0.4^{\circ} \mathrm{C}$, and $17.6 \pm 1.3^{\circ} \mathrm{C}$ and salinity was $33.9 \pm 0.1 \mathrm{psu}, 31.4 \pm 0.1 \mathrm{psu}$, and $33.5 \pm 0.2 \mathrm{psu}$ in May, August, and November, respectively. Usually in this area, concentration of nutrients such as nitrogen $(\mathrm{N})$ and phosphorus $(\mathrm{P})$ com- pounds were high in winter and low in summer. The value of dissolved inorganic nutrients at the surface layer is less than the value at the bottom (Fig. S1). These data were obtained from the marine environmental monitoring network by the Ministry of Oceans and Fisheries [25].

\subsection{Seawater Sampling and Microalgae Identification}

Seawater samples were collected from surfaces at depths of $5 \mathrm{~m}$ and $10 \mathrm{~m}$ near the pilot plant of lithium recovery field near the Okgye Harbor. The seawater was sampled once a month except March during Feb - Oct 2013. Three points of vertical seawater samples $(0 \mathrm{~m}, 5 \mathrm{~m}$, and $10 \mathrm{~m})$ were collected at the pilot plant station. Three 1-liter samples for each depth were immediately preserved on board with Lugol's solution and subsamples of 200 $\mathrm{ml}$ were obtained after natural concentration of $48 \mathrm{~h}$ for cell counts. All samples were thoroughly shaken and aliquots of $1 \mathrm{ml}$ of subsamples were allowed to settle in the counting chambers. Microalgae was identified and counted by light microscope (LM) (Axioplan; Carl Zeiss, Oberkochen, Germany) using the Utermöhl settling technique [26]. The cells were counted three times at x400 magnification of microscope and then converted to cell $/ \mathrm{ml}$. The majority of the cells were identified up to the level of species.

\subsection{Exposure of Lithium Manganese Oxide Disks to Seawater}

The lithium adsorbent used in this study was a granular form of porous lithium manganese oxide (LMO) cast in the form of a disk (pellet, diameter $30 \mathrm{~mm}$, thickness $4 \mathrm{~mm}$ ). The granular form of manganese oxide was made from powdered manganese oxide through simple mixing, forming and calcination processes. The process is to obtain a precursor mixture suitable for molding using an LMO precursor composed by lithium carbonate and manganese carbonate and a binder (water glass, sodium silicate solution), then form it into a sphere using extrusion equipment, heat-treated to form solid. The shape of the spherical adsorbent has the advantage of increasing packing density and improving stability to the polishing environment. The cast disc-shaped adsorbent has a porous structure to facilitate the passage of seawater (Fig. 1).

For the periodical and seasonal characteristics of biofouling by microalgae on the lithium adsorbents, test samples were immersed in the pilot plant in the seawater near Okgye harbor. Test samples, $\mathrm{LD}$ were packed in nylon fabric and installed into a PVC cage. This cage hung on the pilot plant construction and was immersed in seawater up to a depth of $7 \mathrm{~m}$. These adsorbents were retrieved after $7 \mathrm{~d}, 14 \mathrm{~d}$, and $21 \mathrm{~d}$ and investigated regarding the abundance of species of attached microalgae. For detaching the micro algae samples from the adsorbent's surfaces, half of the adsorbents are immersed in $15 \mathrm{ml}$ sterilized seawater using a vibrator with 90 s. Lugol's solution is added and aliquots of $1 \mathrm{ml}$ of subsamples were counted and identified using an optical microscope. The changing morphology of porous pellet surfaces after exposure is analyzed using SEM (S-3500N; Japan, KBSI Chuncheon Center). Samples were prepared for electron microscopy by drying and coating them with gold and palladium under a 2-kV extra high-tension condition. This experiment was conducted three times: May (20th May 10th June, spring), August (13th August - 3rd September, summer), and November (24th October - 15 November, fall) in 2013. 


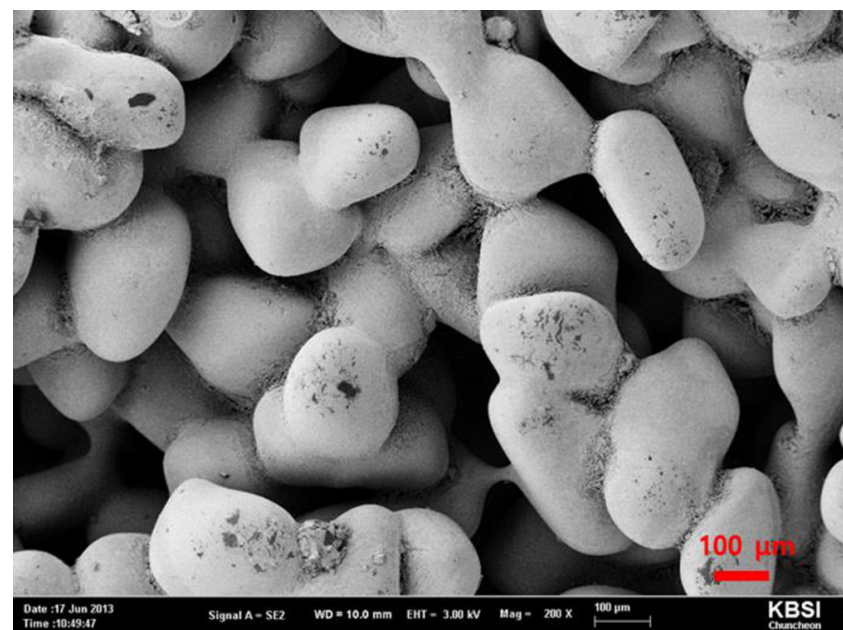

Fig. 1. SEM image of LD surface after $7 \mathrm{~d}$ exposing to seawater $(3.00$ $k V, 200 x)$.

\section{Results}

\subsection{Abundance and Composition of Microalgae in Seawater}

Abundance and species composition of microalgae are determined by biological factors owing to ingestion of high-level consumers and nonbiological factors such as nutrients, water temperature, and light intensity [27, 28]. Generally, phytoplankton bloom occurs primarily in spring and autumn in Korea due to biological and environmental factors [29, 30]. Total microalgal abundance was the highest in May and lowest in February in the Okgye area of Gangneung during February to October 2013 (Table 1). These values represented the average number of microalgae cells collected from sea water at $0 \mathrm{~m}$ (surface), $5 \mathrm{~m}$, and $10 \mathrm{~m}$ depth, respectively. The density of microalgae increased from April (438 x $10^{3}$ cell/L) and peaked in May and lowered in June and August due to frequent precipitation, and subsequently increased again in September. In February, microalgae are rarely present, suggesting that there is an exceptionally rare occurrence at $10 \mathrm{~m}$ depth, because strong winds and active vertical mixing in winter causes concentration of microalgae to be below the critical depth [28].

During the investigation periods, a total of 99 species of microalgae were identified. Seventy-one species belonged to Heterokontophyta (41 genera, 2 phyla) and 28 species belonged to Dinophyta (15 genera, 2 phyla). In this area, Bacillariophyceae were predominant at $97 \%$, Dinophyta were $2.6 \%$, and Dictychophyceae were $0.4 \%$. Especially, centric diatoms were 85.7\% and pennate diatoms were $11.3 \%$. Monthly dominant species were changed. In April, Leptocylindrus danicus (38.7\%) and Nitzchia spp. (23.1\%) were the dominant species. L. danicus continuously increased by $80.1 \%$ in May. In June, July, and September, Guinardia sp. were predominant with concentrations of $75.3 \%, 68.8 \%$, and $39.9 \%$, respectively. In August and October, the Cyclotella sp. were the most abundant with concentrations of $29.0 \%$ and $24.7 \%$, respectively. The number of identified species was more diverse from July to October. Moreover, after August, there was a decrease the dominance rate for specific species but various species were present this area. The monthly dominant microalgae are listed in Table S1. All dominant species were widely distributed species that exist in the temperate coastal area of the northern hemisphere. L. danicus has been recorded to be the most dominant species in spring [31-33] and Chaetoceros spp. is the most frequently observed species and they have steady appearance regardless of the season in the coastal area of East Sea [31-35]. G. cylindrus was predominant in June, July, and September in this study. Dictycocha sp. was relatively rich in February. However, the total number of cells counted in February was very rare, and the largest number was identified in August, which is supported by other studies that Dictycocha sp enriches at high water temperatures [36].

As shown in results above, the composition of plankton species in seawater of the Okgye Sea was changed by season. This is due to the complex effect of temperature and water mass characteristics. The composition of these seasonal planktons is not different from the results of the long-term studies of the Japan sea (far East Sea) in the past [37]. Differences in the community structure of phytoplankton are apparent in summer and winter when the large differences of temperature. In winter, diatoms were dominate, such as Skeletonema spp., which has withstand low temperatures and low light condition. And in the summer, the abundances of Dinophyta were increases. As a whole area of the Korean peninsula, the species composition was similar, but the predominant species varied from season. In Asan Bay, western estuary of Korean Peninsula, Skeletonema spp. or Thalassiosira spp. predominates in winter and Rizosolenia spp. and Pseudo-nitzschia spp. were dominated in spring [28]. In the Yellow Sea, changes in plankton species are more diverse due to freshwater inflows and silty (clay) environment [38]. Leptocylindrus spp. and Guinardia spp. dominated in May and June in the Uljin Sea of the East Sea located south from this study area, but Thalassiosira spp. were extremely dominated in April, unlike the results of this study [39]. Therefore, predominant species may appear differently depending on the seasons and regions of the Korean Peninsula, so it is essential to investigate the ambient seawater when evaluating exposure to biofouling.

\subsection{Seasonal Changes in Species and Quantity of Microalgae Attached to the Lithium Manganese Oxide Disk}

3.2.1. Concentration of attached microalgae on LD surface Attached microalgae on the surface of $\mathrm{LD}$ are represented by the

Table 1. Monthly Abundances of Phytoplankton by Depth (cell/mL)

\begin{tabular}{lcccccccc}
\hline & Feb & Apr & May & Jun & Jul & Aug & Sep & Oct \\
\hline Surface & 3 & 438 & 585 & 10 & 212 & 28 & 105 & 20 \\
$5 \mathrm{~m}$ & 2 & 510 & 526 & 27 & 339 & 54 & 151 & 33 \\
$10 \mathrm{~m}$ & 3 & 277 & 632 & 182 & 215 & 58 & 157 & 41 \\
No. of species & 5 & 23 & 15 & 11 & 51 & 45 & 51 & 56 \\
\hline
\end{tabular}


number of cells per unit area $\left(\mathrm{cm}^{2}\right)$. The overall average adherent cells were 5,830 cells $/ \mathrm{cm}^{2}$. The mean number of adherent cells was 7,060 cells/$/ \mathrm{cm}^{2}$ in May, 2,099 cells $/ \mathrm{cm}^{2}$ in August, and 8,332 cells $/ \mathrm{cm}^{2} \mathrm{~m}$ in October (Fig. 2). Total adhesion of cells were highest in October; the maximum adherence of cells was observed to be 11,746 cells $/ \mathrm{cm}^{2}$ on the LD surface that was exposed for $21 \mathrm{~d}$ in May. In May and October, the adhered number of microalgae increased with longer exposure period. In May, the increase in the amount of adherence between 7 and 14 d relatively small increases (about 25\%) compared to the increase from rapidly between the $14 \mathrm{~d}$ and 21d exposure periods. The adherence amount for the $21 \mathrm{~d}$ exposure was more than two times that for the $14 \mathrm{~d}$ exposure. In October, the attached microalgae density was increased with exposure time and rapidly accreted during more earlier period of $7 \mathrm{~d}-14 \mathrm{~d}$. In August, the adherence of microalgae was the highest at 4,706 cells $/ \mathrm{cm}^{2}$ during a $14 \mathrm{~d}$ exposure period and decreased after $14 \mathrm{~d}$. Overall, the amounts of adhering microalgae to $\mathrm{LD}$ were higher in May and October, and lower in August. The high attachment rate of microalgae in May is related to the high density of ambient sea water in Okgye. However, in October, there is no effect owing to microalgae abundances in ambient seawater. The increased abundance of the standing crops of microalgae in the spring and less in the summer is affected by the biomass of microalgae in the ambient seawater. Despite the lower abundance of microalgae in ambient water column in October than in August, the amount of adhesion microalgae increased to the level of May.

Comparing the identified species with ambient seawater, the pennate diatom was observed to be the most abundant, and several species were not observed in seawater (Table S2). Odontella longicrusis, Bacillaria paxillifer, Mastogloia sp., Pleurosigma angulatum, Pleurosigma decorum, Pseudo-nitzschia delicatissima, and Pseudo-nitzschia sp. were not observed in seawater at the genus level. The proportion of diatom present in all identified microalgae is about $97 \%$ in both seawater and LD surface. However, the composition of diatoms was different in seawater and $\mathrm{LD}$. The diatom of centric was $85.7 \%$ and that of pennate was $11.3 \%$ in ambient seawater but, the $\mathrm{LD}$ surface has exceeded the pennate diatom by $67 \%$ while the centric diatom was $29.5 \%$. Consequently, the morphological characteristics such as the raphes that made EPS were favorable to adhesion dominate the adhesion efficiency.

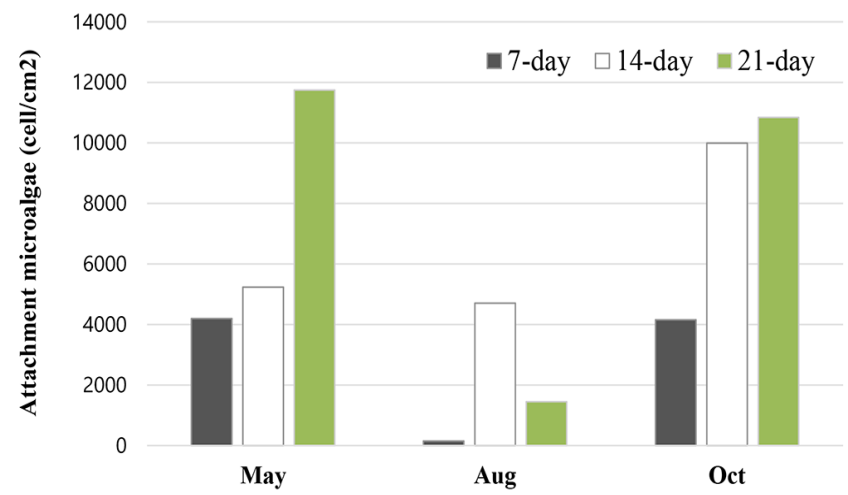

Fig. 2. Seasonal distributions of attachment microalgae on the absorbent's surface according to exposing periods.

\subsubsection{Seasonal succession of diatom species on LD surface}

The dominant biofilm forming the microalgae species on the $\mathrm{LD}$ surface demonstrated either similarities or differences according to exposure time and season. The Cylindrotheca sp., Cyclotella sp., Guinardia sp., Licmophora sp., Navicula sp., Thalassionema sp., and Prorocentrum sp. were the most frequently observed diatom genera in this study. Interestingly, in this study, centric diatoms such as Cyclotella sp. and Guinardia sp. were primarily identified in spring time. As shown in Table S2, fouling diatoms for artificial submerged surfaces were primarily related to pennate diatoms (benthic). The adhering of microalgae to the $\mathrm{LD}$ surfaces was largely affected by environmental changes due to seasonal causes and the differences of the substrates. The results of this study also indicate that the attached diatoms were related to the season and the phytoplankton composition of ambient seawater. The dominant species of marine phytoplankton are the L. danicus (April and May), the Guinardia spp. (June and July), Cyclotella spp. (August and October), and Guinardia spp. (September) in seawater.

On the LD surface, Guinardia sp. were predominant in spring (May) during the initial $7 \mathrm{~d}$ immersion, which is the second dominant species in May and predominant in June. Although Guinardia sp. is not known to be a major species for biofilm formation, it affects adhesion to $\mathrm{LD}$ surfaces when the microalgae abundance increases during phytoplankton bloom in spring. However the dominant species was succeeded by $C$. closerium after $21 \mathrm{~d}$. For the seven day exposure, Guinardia spp. accounted for $86 \%$, but after the $14 \mathrm{~d}$ exposure, the dominance rate was reduced to $62 \%$ and the minimum relative abundance after $21 \mathrm{~d}$ was observed to be $29 \%$. The relative abundance of $C$. closerium increased from $7.9 \%$ to 62.3\%; a few exist in sea water in May and June. Yang et al.,[10] also demonstrated that the number of diatoms and EPS significantly increased after two weeks of exposure. In August, fouling is dominated by Cyclotella spp. at $28.3 \%$ during the $7 \mathrm{~d}$ immersion period. Cyclotella sp. was the most abundant diatom in Okgye seawater in this period. C. closerium was not dominant in the early stage of summer but it increased to $75 \%$ during the $14 \mathrm{~d}$ exposure period and decrease to $26 \%$ after $21 \mathrm{~d}$. The percentage of $C$. closerium decreased as the total fouling amount was lower at $21 \mathrm{~d}$ of exposure, but the fouling species increased, such as Cyclotella spp. (19\%), Nitzschia spp. (10\%) and Thalassionema spp. (12\%). This is also related to the increase in species present in the seawater since summer (Table 1). Especially in August, species belonging to Dinoflagellates were additionally observed in seawater, and thus found Protoperidinium sp. and Dinophysis sp. on the LD surface (included in Others in Table S2). The appearance of various species seems to have interfered with the dominance of one species. The Navicula sp is a ubiquitous biofilm forming diatom. In this study, Navicular sp. were predominant for $21 \mathrm{~d}$ in fall. In spring and summer, biofouling diatoms of early stages were significantly affected by ambient water column. However, aver a longer exposure time and as biofilm accumulates, it remains greater attachment species such as $C$. closerium after the $7 \mathrm{~d}$ exposure in fall, $L$ paradoxa was the abundant species with $31.1 \%$ after Navicula sp. After the $14 \mathrm{~d}$ and $21 \mathrm{~d}$ exposure periods, $C$. closerium also increased with exposure time. The biofilm composition of phytoplankton was changed in May and August as the immersion time increased 
Table 2. Relative Abundances of Dominant Attachment Diatoms

\begin{tabular}{|c|c|c|c|c|c|c|c|c|c|}
\hline & \multicolumn{3}{|c|}{ May } & \multicolumn{3}{|c|}{ Aug } & \multicolumn{3}{|c|}{ Oct } \\
\hline & 7-d & 14-d & 21-d & 7-d & 14-d & 21-d & 7-d & 14-d & 21-d \\
\hline Cylindrotheca closerium & 7.90 & 23.7 & 62.3 & 6.60 & 74.8 & 25.9 & 9.80 & 15.9 & 20.6 \\
\hline Cyclotella spp. & & & & 28.3 & 7.90 & 19.0 & & & \\
\hline Guinardia spp. & 86.5 & 62.7 & 28.5 & & 0.8 & & 0.40 & 0.20 & \\
\hline Licmophora spp. & & & & & & & 31.1 & 3.40 & 16.8 \\
\hline Leptocylindrus danicus & 2.30 & 1.80 & 0.40 & & & & & & \\
\hline Navicula spp. & & & & & & & 41.7 & 60.7 & 46.0 \\
\hline Nitzschia palea & 2.20 & 5.50 & 4.80 & 4.70 & 4.90 & 10.2 & 8.10 & 4.60 & 2.60 \\
\hline Thalassionema & & & & & 3.40 & 12.2 & 3.00 & 0.50 & 0.30 \\
\hline Prorocentrum spp. & & & & 11.3 & & & & 0.40 & \\
\hline Others & 1.10 & 6.30 & 4.00 & 49.1 & 8.20 & 32.7 & 5.90 & 14.3 & 13.7 \\
\hline sum & 100.0 & 100.0 & 100.0 & 100.0 & 100.0 & 100.0 & 100.0 & 100.0 & 100.0 \\
\hline
\end{tabular}

(Table 2). The relative abundance of pennate diatoms was increased over time in spring. Compared with fouling amounts, the relative abundances of pennate diatom were positively related with number of attachment cells. Especially, C. closerium was most related to biofilm of lithium adsorbents in this area.

\section{Discussion}

It is known that the concentration and species distribution of microalgae causing biofouling on the inorganic surface depends on the seasonal effects (temperature, salinity etc.), the attachment ability of the microorganism and the properties of the substrates. Here, the characteristics of attachment microalgae to the $\mathrm{LD}$ surface are discussed through changes in the diatom community according to seasons and exposure periods.

From the above results, it is founded that dominant species which were initially adhered was changed by seasons. The centric diatoms Gunardia sp. and Cyclotella sp. were dominant, in early May and August, respectively unlike pennate diatoms which are known to be dominant adhering species. In particular, Guinardia spp. has an initial dominance rate of about $87 \%$. This is due to the abundance of Guinardia spp. in seawater due to the plankton bloom resulting from the rises of temperature in spring. The Guinardia spp. has never been recorded as a fouling species in previous studies. In this study, Gunardia's occupancy in spring lasted about 2 weeks in spring due to the continuous supply from seawater and $\mathrm{LD}$ provided a good habitat. Thus, biofilm composed diatom on lithium adsorbents were abundant with centric diatom in the initial stage owing to the abundance of ambient seawater in the Okgye Sea. This kind of small and centric type of diatoms has a large growth rate in spring [40]. This means that the abundance of microalgae in seawater is also an important factor affecting biofouling as well as the adherence ability of microalgae. Standing crops of phytoplankton in seawater are induced by environmental factors such as seasonal effects. Recent study has shown that the diatom fouling increased in the calm period (pre- and post-monsoon) due to seasonal effects of the Yellow Sea near the Korean peninsula [10]. These seasonal effects can induce changes in the species composition of diatoms attached to artificial surfaces and it can result in serious fouling problems depending on species [35].

However, if the substrate is exposed for a longer period, it has been found that adhesion abilities of microalgae become more important. Pennate diatoms, as they are known constitute the major portion of the biofilm because they have raphe(s) that enables to attach and glide over the substratum and settle down on the surface of artificial structures through the physical processes [11]. In spite of the abundance of microalgae in seawater being lower in fall than other seasons, the proportion of pennate species increased in fall. At this time, the number of adherent cells increased sharply between $7 \mathrm{~d}$ and $14 \mathrm{~d}$ because of the high percentage of pennate diatoms in the early biofilm (Fig. 3). This was also the case in spring, where the increase in adhered microalgae was small between $7 \mathrm{~d}$ and $14 \mathrm{~d}$, but increased rapidly between 14 $\mathrm{d}$ and $21 \mathrm{~d}$, which is attributed to an increase in pennate diatom in the later period. In this study, Navicula sp. and C. closterium were found to be the most influential pennate diatoms on the $\mathrm{LD}$ surface. The Navicula sp, which is ubiquitous biofilm forming diatom. Navicula sp. has increased adhesion capability as they secrete the mucilaginous at two points and therefore, they can easily attach even to rough substrates [41]. In this study, Navicula spp. were not found as an adherent species in spring and summer, but it accounted for more than $40 \%$ over the entire period of fall. It is related to the abundance of Navicula sp. in seawater in the

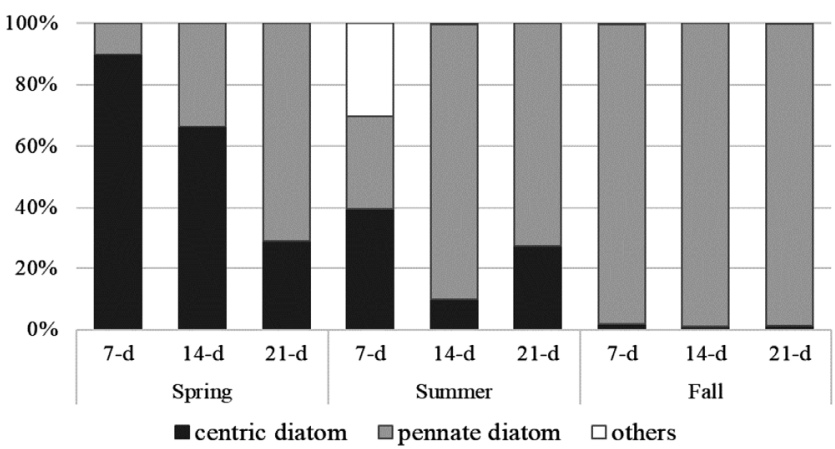

Fig. 3. Changes in microalgae composition according to season and exposure period (classification by shape of diatom). 
Table 3. Identified Diatom Species on Submerged Artificial Surfaces

\begin{tabular}{|c|c|c|c|}
\hline Materials & Area & Species (or genera) & References \\
\hline $\begin{array}{l}\text { Glass, Acryl, Titanium, Copper, } \\
\text { painted slide glass }\end{array}$ & Incheon, Yellow Sea, Korea & $\begin{array}{l}\text { Amphora coffeaeformis } \\
\text { Synedra tabulate, Licomophora paradoxa, } \\
\text { Melosira. nummuloides }\end{array}$ & {$[12]$} \\
\hline Glass (fibred, coupons) & Dona Paula Bay, India & $\begin{array}{l}\text { Navicula transitans var. derasa f. delicatula } \\
\text { Amphora coffeaeformis, T. nitzschioides, } \\
\text { Cylindrotheca. closterium and N. sigma }\end{array}$ & [13] \\
\hline $\begin{array}{l}\text { Concrete plates } \\
1 \mathrm{~m}, 3 \mathrm{~m}, 7 \mathrm{~m} \text { depth }\end{array}$ & $\begin{array}{l}\text { Punta Madonna } \\
\text { Northern Adriatic Sea }\end{array}$ & $\begin{array}{c}\text { Berkeleya, Navicula, Licomopora, } \\
\text { Achnanthes, Nitzschia }\end{array}$ & [14] \\
\hline $\begin{array}{l}\text { Stainless steel (SS), } \\
\text { polystyrene (PS) }\end{array}$ & Dona Paula Bay, India & Navicula, Amphora & {$[5]$} \\
\hline $\begin{array}{l}\text { ship hulls } \\
\text { - AF (copper SPC) ship } \\
\text { - FR ship }\end{array}$ & Miami, FL, USA & $\begin{array}{l}\text { Achnanthes, Amphora, Navicula, } \\
\text { Lampriscus, Thalassiophysa (new diatom) }\end{array}$ & {$[15]$} \\
\hline $\begin{array}{l}\text { Lithium manganese oxide disk } \\
\text { (LD) }\end{array}$ & Okgye, East Sea, Korea & Cylindrotheca, Cyclotella, Guinardia, Licmophora, Navicula & This study \\
\hline
\end{tabular}

fall. In spring and summer, the centric diatom was dominant in seawater and species composition did not vary, but after July, the apparent frequency of pennate diatom increased with the advent of various species. Hence, Navicula sp. can be regarded as a species that reflects seasonal influences during the study period. On the other hand, C. closterium and Nitzchia plea was attached regardless of season and exposure duration throughout the study periods. Nitzchia plea appeared on all LD surface, but the total occurrence was less than $10 \%$ of each sample. The longer the exposure time of $\mathrm{LD}$ to seawater, the higher the dominance rate of $C$. closterium, and accounted for up to $74 \%$ in August. This is related to biofilm thickness and the propagation after attachment of $C$. closterium. According to a study of Daume [42] and Kingston [43], the biofilm of C. closterium, which grew for $19 \mathrm{~d}$, increased the settlement by 8 times compared to the biofilm of $3 \mathrm{~d}$, which means that the old non-growth culture of the stationary phase of $C$. closterium could induce settlements rather than the exponentially growing culture. The specific growth rate was also higher than other diatom species [10]. Therefore, mature biofilm of approximately $20 \mathrm{~d}$ old has the possibility of including a considerable number of accumulated $C$. Closterium according to a limited habitat of the $\mathrm{LD}$ surface.

$\mathrm{LD}$ is a substance that can be directly exposed to the sea to recover lithium using ion exchange process. The artificial substrates such as $\mathrm{LD}$ exposed to the ocean can act as a major factor in the growth of benthic diatoms with physical and chemical factors that vary with environmental conditions, such as natural substrates such as sediment particles [41, 44, 45]. Several studies have been reported that the adhesion of diatom species on the artificial substrate in seawater (Table 3). Various species such as A coffeaeformis, S. tabulate, L. paradoxa, and M. nummuloides were attached to glass, acrylic, titanium, copper, and anti-fouling (AF) coated slide glass [12]. The adhesion rate of microalgae was higher in glass than other materials. Patil and Anil [13] reported that the $N$. transitans var. derasa $f$. delicatula, A. coffeaeformis, T. nitzschioides, C. closterium, and N. sigma were the dominant fouler of exposure to two types of glass; fibred and coupons. There was no species specificity between two fibred and coupon types due to of the same material made by glass. Exposure of the concrete plate from the Northern Adriatic Sea resulted in dominance of Berkeley sp., Navicula sp., and Licomopora sp. [14]. In Florida, US, species such as Achnanthes sp., Amphora sp., Navicula sp., Lampriscus sp., Thalassiophysa sp., and Achnanthes sp. were observed in the hull of an in-service ship [15]. Despite reports on the differences in species depending on the type of material [41] as well as geographic location [46]. Amphora sp. and Navicula sp. were commonly identified. However in this study, Achnanthes spp and Amphora spp. were rarely identified. Amphora spp. also has a characteristic similar to Navicular sp. due to its double-raphes structure, and thus appears as a chronic fouling species regardless of latitude and longitude. Exceptionally Achnanthes spp. and Amphora spp. were not identified as a major species in seawater at the East Sea. One suggestion is that these two species frequently appeared in the soft sedimentary layer in the West Sea and that Amphora spp. and Nitzschia spp. were reported to increase in the eutrophic environment. These two species with strong adhesion can be considered to inhabit primarily marine sediments, not seawater.

In addition, Attachment of microorganisms during the initial physical process of fouling preferentially induces attachment of benthic diatoms having morphology favorable for adhesion. At this time, recruit rate of microalgae was affected by surface characteristics such as effective size of adhesion or roughness [4, 23]. According to Sweat and Johnsond [47], the pennate diatom had a higher adhesion rate on the smood surface than on the coarse roughness surface. However, centric diatoms such as L. danicus and Cosinodiscus sp. showed a higher adhesion rate on the surface with fine roughness than the smood surface, which was also consistent with the results of this study. The $\mathrm{LD}$ used in this study is a pressed grain with $100-200 \mu \mathrm{m}$ diameters of $\mathrm{LiMnO}_{4}$ and has a porous structure to increase the surface area (Fig. 1). Depending on the shape and size of the diatom, the characteristics attached to the $\mathrm{LD}$ surface were different. Fig. 4 shows the appearance of the various diatom attached to the $\mathrm{LD}$ surface. Smaller centric diatoms, such as Cyclotella sp, exist in embedded form between LD particles (Fig. 4 (a)). In case of diatoms with longer shapes 

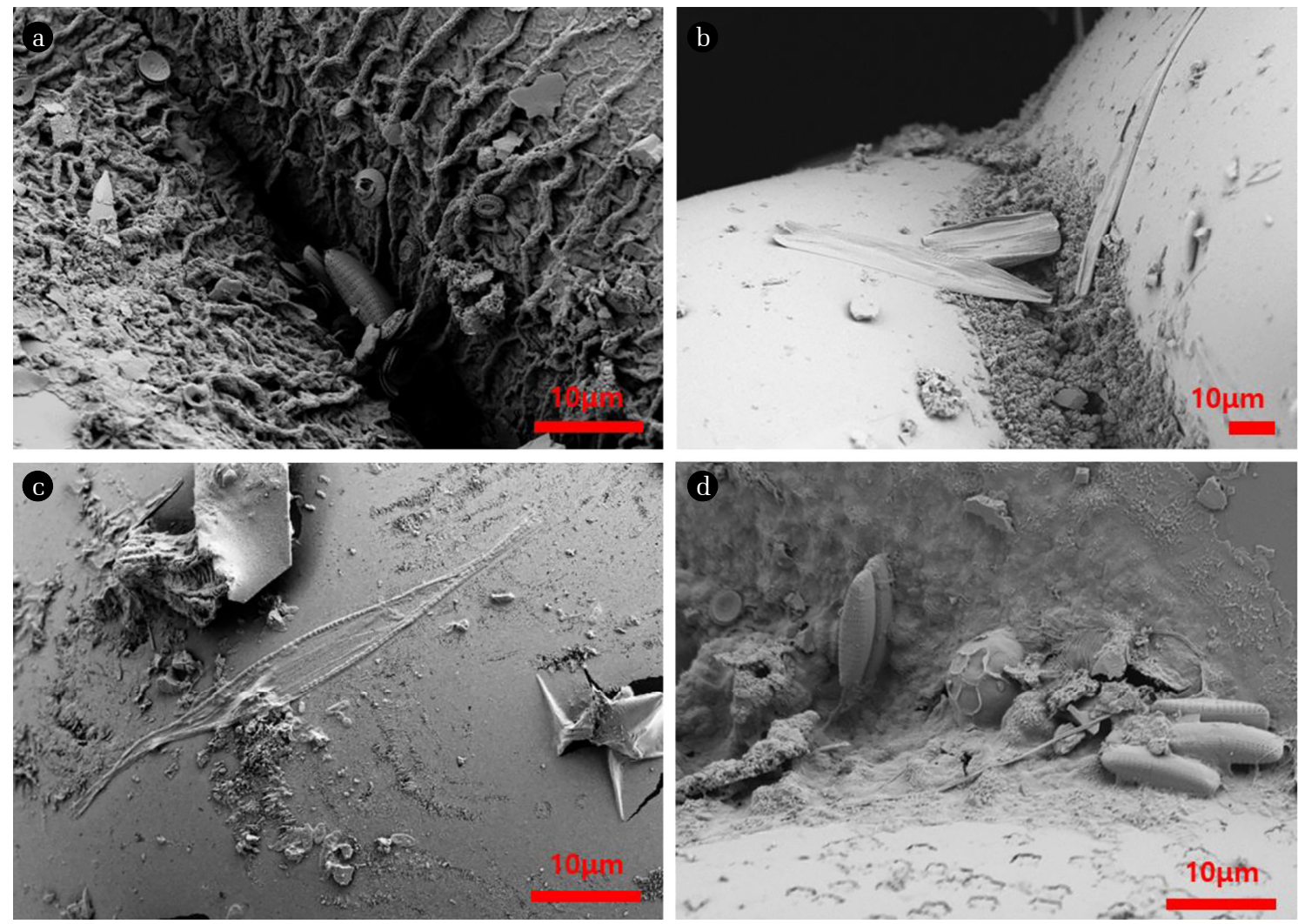

Fig. 4. Various attachment patterns of diatom attached to LD surface (a) Small microalgae in the stucked between granular adsorption materials, (b) attachment of Licomophora (c) Cylindrotheca attached to surface (d) Surface fouling appearance of LD exposed $21 \mathrm{~d}$.

such as Cylindrotheca sp., Licmophora sp., and Nitzschia sp., they can be attached using long and flexible cell end even in the curvature surface between LD particles (Fig. 4 (b), (c)). The Navicula sp. like species rolled over $\mathrm{LD}$ surface and settled in a groove between the particles. The biofilm growth is rapidly accreted when the exposure time is prolonged, the slime builds up and covers pre-existing microbiome (Fig. 4 (d)). At this stage, it would be developed into macro-fouling by large algae such as Rhodophyta or Phaeophyceae, and there is a possibility of directly affecting the lithium recovery rate by ion exchange.

As discussed above, the major chronic species were similar, regardless of the low latitudes of Dona Paula [13] or Florida [48] and the high latitude of Northern Adriatic Sea [14]. However, when an $\mathrm{AF}$ (anti-fouling) substance such as a Cu-based substance is treated on the exposed surface, microalgae that can withstand the $\mathrm{AF}$ agent adhere and survive. Shim et al. [12] have found $H$. virgate, L. abbreviata, and M. nummuloides species resistant to toxicity of AF. Hunsucker et al. [15] found attachment microalgae, such as Thalassiophysa species with AF-resistance by Cu-based AF and silica-based AF. The $\mathrm{LD}$ used in this study uses adhesives, when molding lithium manganese oxide powder, but has obtained research results that do not affect the marine ecosystem. In addition, through the seawater leaching test for the prepared $\mathrm{LD}$, it was confirmed that only a small amount of lithium $\left(\mathrm{Li}^{+}\right)$and manganese $\left(\mathrm{Mn}^{2+}\right)$ ions were eluted from LD. It had not eluted component that affect ecological functions such as growth and reproduction of the microalgae. Therefore, the species observed on $\mathrm{LD}$ surfaces were more sensitive to seasonal changes than $\mathrm{LD}$ substances. Compared with the fouling characteristics of the materials used in other studies, the environmental changes due to seasonal reasons rather than specificity due to $\mathrm{Li}$ or $\mathrm{Mn}$ seemed to have a dominant effect on the microalgae.

It is also noticed a decrease in fouling in August. It can be considered that there was a typhoon before recovering the samples exposed for $21 \mathrm{~d}$ and this had an effect on the reduction in the amount of fouling. In other words, the possibility of removing contaminants caused by microalgae in the physical process was observed. In particular, a relative decrease in C. closterium was observed, which means that diatoms that are widely attached to the $\mathrm{LD}$ surface are also easy to remove by physical process such as waves in shallow seawater layer.

\section{Conclusions}

The microalgae attached to the surface of lithium manganese oxide disk in the Okgye area is affected by the microalgae species composition of the ambient seawater and by the adhesion properties of microalgae itself. In May, during the spring bloom, the existing phytoplankton in the ambient seawater affected the attached frequency and species. In particular, there was a new discovery that floating species such as Guinardia sp. presented as extreme domi- 
nant species on the $\mathrm{LD}$ surface. In Okgye Sea, biofouling amounts of $\mathrm{LD}$ surfaces increased related with pennate (benthic) diatom such as Cylindrotheca closterium and Navicula sp. Over extended periods exposure to seawater, Cylindrotheca closterium were accrued in biofilm and exasperate the biofouling in all experimental seasons. In this study, a micro-succession occurred during the experimental period. The pioneer species can be regarded as the dominant species of the surrounding seawater such as Guinardia sp. and the later species were considered as Cylindrotheca closterium with a high adherence. In addition, the $\mathrm{LD}$ surface structure in the form of particles formed also plays an important role in attachment of the microalgae. According to the results of this study as well as previous studies, benthic diatom affects severe fouling as it is exposed for longer periods. However, if there are numerous floating diatoms in seawater, it is necessary to consider the effect on these species at the early stage of biofouling within $7 \mathrm{~d}$. In addition, as the timing of the rapid increase of the attached species varies depending on the season, it is necessary to vary the exposure period for each season when $\mathrm{LD}$ is to be exposed to seawater. The results of this study can provide reliable data in determining the exposure season and duration in order to minimize fouling effects and improve the recovery of seawater mineral resources using lithium manganese oxide.

\section{Acknowledgment}

This research was supported by the national research project titled "The Development of Technology for Extraction of Resources Dissolved in Seawater," of the Korea Institute of Geoscience and Mineral Resources (KIGAM), which is funded by the Ministry of Oceans and Fisheries.

\section{Author Contributions}

J-A.K. (Ph.D. researcher) conducted all experiments and writing paper. S.J. (Ph.D. senior researcher) performed laboratory experiments. K-S.C. (Ph.D. senior researcher) organized field setting and performed field experiments. H-O.Y. (Ph.D. senior researcher) organized overall experiments and writing paper.

\section{References}

1. Callow ME, Callow JE. Marine biofouling: a sticky problem. Biologist (London) 2002;49:10-14..

2. Yebra DM, Kiil S, Dam-Johansen K. Antifouling technology-past, present and future steps towards efficient and environmentally friendly antifouling coatings. Progress in Organic Coatings 2004;50:75-104.

3. Kim J-A, Kong M, Kim J-H, Chung K-S, Eom C-Y, Yoon H-O. Identification of marine bacteria affecting lithium adsorbents in seawater. Environ. Geochem. Heal. 2013;35:311-315.

4. Schultz MP. Effects of coating roughness and biofouling on ship resistance and powering. Biofouling 2007;23:331-341.
5. Mitbavkar S, Anil AC. Seasonal variations in the fouling diatom community structure from a monsoon influenced tropical estuary. Biofouling 2008;24:415-426.

6. Marhaeni B, Radjasa OK, Khoeri MM, Sabdono A, Bengen DG, Sudoyo H. Antifouling Activity of Bacterial Symbionts of Seagrasses against Marine Biofilm-Forming Bacteria. J. Environ. Protec. 2011;2:1245-1249.

7. Schultz MP, Bendick JA, Holm ER, Hertel WM. Economic impact of biofouling on a naval surface ship. Biofouling 2011;27:87-98.

8. Park S, Kwon S, Lee Y, Koh W-G, Ha JW, Lee S. Study on Anti-biofouling properties of the surfaces treated with perfluoropolyether. App. Chem. Eng. 2012;23:71-76.

9. Cooksey BW and Cooksey KE. Can diatoms sense surfaces?: state of our knowledge. Biofouling 1992;5:227-238.

10. Yang C, Wang J-H, Yu Y, Liu S, Xia C. Seasonal variations in fouling diatom communities on the Yantai coast. Chin. J. Oceanol. Limnol. 2015;33:439-446.

11. Molino PJ, Wetherbee R. MINI REVIEW: The biology of biofouling diatoms and their role in the development of microbial slimes. Biofouling 2008;24:365-379.

12. Shim J-H, Kang J-H, Cho B-C, Kim W-S. The Microalgal Attachment and its Growth on the Artificial Surfaces Immersed in Seawater: I Attachment and Micro-succession. J. Kor. Soci. Ocean 1998;3:249-260.

13. Patil JS, Anil AC. Biofilm diatom community structure: Influence of temporal and substratum variability. Biofouling 2005;21:189-206.

14. Munda IM. Seasonal fouling by diatoms on artificial substrata at different depths near Piran (Gulf of Trieste, Northern Adriatic). Acta Adriatica 2005;46:137-157.

15. Hunsucker KZ, Koka A, Lund G, Swain G. Diatom community structure on in-service cruise ship hulls. Biofouling 2014;30: 1133-1140.

16. Chung KS, Lee JC, Jeong JK, Kim HJ. Lithium-manganese oxides, method for preparing the same, and lithium adsorbent using the same. US Patent 2011;US7,943,113 B2.

17. Chung KS, Lee JC, Lee H. Lithium recovery device using separator reservoir, lithium recovery method and lithium adsorption/desorption system using the same. US Patent 2014; US8741150B2.

18. Ryu T, Ryu JC, Shin J, Lee DH, Kim YH, Chung K-S. Recovery of lithium by electrostatic field-assisted desorption process. Ind. Eng. Chem. Res. 2013;52:13738-13742.

19. Hong H-J, Park I-S, Ryu J, Ryu T, Kim B-G, Chung K-S. Immobilization of hydrogen manganese oxide (HMO) on alpha-alumina bead (AAB) to effective recovery of $\mathrm{Li}^{+}$from seawater. Chem. Eng. J. 2015;271:71-78.

20. Ryu T, Shin J, Lee D-H, et al. Improvement of lithium adsorption capacity of porous cylinder-type lithium manganese oxide introduction of additive. Mater. Chem. Phys. 2015;167:225-230.

21. Ryu T, Haldori Y, Rengaraj A, et al. Recovery of lithium ions from seawater using a continuous flow adsorption column packed with granulated chitosan-lithium manganese oxide. Ind. Eng. Chem. Res. 2016;55:7218-7225.

22. Kong M, Yoon H-O, Kim J-A, Bae J, Chung K-S. Application of CLSM and SEM analysis for biofouling study. In: Oceans 2012; 21-24 May 2012; Yeosu. p. 1-13. 
23. Jeong S, Kim J-A, Kim H, Chung K-S, Yoon H-O. Identification of preponderant marine bacteria and their biofouling characteristics on adsorbents of different size and shapes in seawater. J. Mar. Sci. Technol. 2018;26:458-464.

24. Kim J-A, Kong M, Yoon H-O, Ryu J, Kim B-G, Chung K-S. Biofouling of marine phytoplankton on the lithium recovery adsorbents from pilot plant in Gangneung, Korea. In: OCEANS 2014;7-10 April 2014; Taipei. p. 1-4.

25. The Ministry of Oceans and Fisheries [Internet]. Available from: https://www.meis.go.kr/mei/observe/port.do.

26. Utermöhl H. Zur Ver vollkommung der quantitativen phytoplankton-methodik. Mitt.- Int. Ver. Theor. Angew. Limnol. 1958;9:1-38.

27. Sin Y, Richard LW, Anderson IC. Spatial and Temporal Characteristics of Nutrient and Phytoplankton Dynamics in the York River Estuary, Virginia: Analyses of Long-Term Data. Estuaries 1999;22:260-275.

28. Yi S, Sin Y, Yang S, Park C. Seasonal characteristics of phytoplankton distribution in Asan Bay. Ocean Polar Res. 2005;27: 149-159.

29. Yamada K, Ishizaka J, Yoo S, Kim H-C, Chiba S. Seasonal and interannual variability of sea surface chlorophyll a concentration in the Japan/East Sea (JES). Prog. Oceanogr. 2004;61: 193-211.

30. Park C, Lee D, Lee C, Yang S, Jung B. Variation in Planktonic Assemblages in Asan Bay During the Winter-Spring Bloom. J. Korean Soc. Ocean. 2008;13:308-319.

31. Kang YS, Choi HC. Ecological Characteristics of Phytoplankton Communities in the Coastal Waters of Gori, Wolseong, Uljin and Younggwang II. Distributions of Standing Crops and Environmental Variables (1992 1996). J. Korean Soc. Ocean. 2002;7:108-128.

32. Jung SW, Kwon OY, Lee JH. Variation and Relationship between Standing Crops and Biomass of Phytoplankton Dominant Species in the Marine Ranching Ground of Tongyeong Coastal Waters from 2000 to 2007. Algae 2008;23:53-61.

33. Kim A-R, Youn S-H, Chung M-H, Yoon S-C, Moon C-H. The Influences of Coastal Upwelling on Phytoplankton Community in the Southern Part of East Sea, Korea. J. Korean. Soc. Ocean. 2014;19:287-301.

34. Kang YS, Choi HC, Lim JH, Jeon IS, Seo JH. Dynamics of the Phytoplankton Community in the Coastal Waters of Chuksan Harbor, East Sea. Algae 2005;20:345-352.

35. Shim J-M, Kwon K-Y, Jeong H-D, Choi Y-K, Kim S-W. Spatial and temporal variability of phytoplankton in relation to environ- mental Factors in Youngil Bay. J. Environ. Sci. Int. 2013;22: 1683-1690.

36. Van der Spoel S, Distephanus/Dictyocha Ratios and Seawater Temperature (Cl.: Mastigophorea, Order: Silicoflagellida). Biological Oceanog. 1987;4:439-445.

37. Chiba S, Saino T. Interdecadal change in the upper water column environment and spring diatom community structure in the Japan Sea: an early summer hypothesis. Mar. Ecol. Prog. Ser. 2002;231:23-25.

38. Oh S, Koh C-H. Distribution pattern of dominant bentic diatoms on the Mangyung-Donjin tidal flat, west coast of Korea. Oceanography 1991;26:24-37.

39. Yoon YH. Bio-environmental characteristics of the Uljin Marine Ranching Area (UMRA), East Sea of Korea. 1. Spatio-temporal distributions of phytoplankton community. J. Korean Soc. Mar. Environ. Energy 2016;19:37-46.

40. Kang Y, Kang H-Y, Kim D, Lee Y-J, Kim T-I, Kang C-K. Temperature-dependent bifurcated seasonal shift of phytoplankton community composition in the coastal water off southwestern Korea. Ocean Sci. J. 2019;54:467-486.

41. Dobretsov S, Albed RMM, Voolstra CR. The effect of surface colour on the formation of marine micro and macrofouling. Biofouling 2013;29:617-627.

42. Daume S, Brand-Gardner S, Woelkering WJ. Preferential settlement of abalone larvae: diatom films vs non-geniculate coralline red algae. Aquaculture 1999;74:243-254.

43. Kingston MB. Growth and motility of the diatom Cylindrotheca Closterium: implications for commercial applications. J. NC. Acad. Sci. 2009;125:138-142.

44. Hoagland KD, Rosowski JR, Gretz MR, Ooemer SC. Diatom extracullular polymeric substances: function, fine structure, chemistry and physiology. J. Phycology 1993;29:537-566.

45. Wetherbee R, Lind JL, Burke J, Quatrano RS. The first kiss: establishment and control of initial adhesion by raphid diatoms. J. Phycol. 1998;34:9-15.

46. Thiyagarajan V. A review on the role of chemical cues in habitat selection by banacles: new insights from larval proteomics. J. Exp. Mar. Biol. Ecol. 2010;392:22-36.

47. Sweat LH, Johnson KB. The effects of fine-scale substratum roughness on diatom community structure in estuarine biofilms. Biofouling 2013;29:879-890.

48. Zargiel KA, Coogan JS, Swain GW. Diatom community structure on commercially available ship hull coatings. Biofouling 2011;27:955-965. 